\title{
Sustainable Development and the Exploitation of Bitumen in Nigeria: Assessing the Environmental Laws Faultlines
}

\author{
Adedoyin Olusegun Akinsulore ${ }^{1}$, Ogechukwu Miriam Akinsulore² \\ ${ }^{1}$ Department of Public Law, Obafemi Awolowo University, Ile-Ife, Nigeria \\ ${ }^{2}$ Faculty of Law, Obafemi Awolowo University, Ile-Ife, Nigeria \\ Email: adakinsulore@oauife.edu.ng,nkwontaoge@gmail.com
}

How to cite this paper: Akinsulore, A. O., \& Akinsulore, O. M. (2021). Sustainable Development and the Exploitation of Bitumen in Nigeria: Assessing the Environmental Laws Faultlines. Beijing Law Review, 12, 113-138.

https://doi.org/10.4236/blr.2021.121007

Received: January 21, 2021

Accepted: March 9, 2021

Published: March 12, 2021

Copyright $\odot 2021$ by author(s) and Scientific Research Publishing Inc. This work is licensed under the Creative Commons Attribution International License (CC BY 4.0).

http://creativecommons.org/licenses/by/4.0/

\begin{abstract}
A major target or the attainment of sustainable development is the maintenance of a healthy environment within the dynamics of natural resource development. In order to achieve this target, mechanisms are put in place to ensure that prior to and during the developmental process of the resource, the environment is reasonably spared of the consequences the invasive exploitation activities. This makes it important for states to put in place laws and regulations that would guarantee the attainment of sustainable development in the natural resources section of its economy. Bitumen is one of the natural resources Nigeria has commenced commercial development in order to diversify its economy from a largely oil dependent one. Study has shown that bitumen, if not carefully monitored, has a potentially more devastating environmental footprint than petroleum. This paper therefore examines two environmental statutes in Nigeria viz the Environmental Impact Assessment (EIA) Act and the National Environmental Standards and Regulation Enforcement Agency (NESREA) Act, with the aim of ascertaining if their provisions are expansive enough to take care of bitumen's processing requirements prior to and during development. The paper finds that these laws, in relation to bitumen development, have serious lacuna that could endanger the attainment of sustainable development in the Nigerian bitumen sector.
\end{abstract}

\section{Keywords}

Sustainable Development, Bitumen, Environment, Exploitation

\section{Introduction}

The desire for a sound economic development of nations, particularly coun- 
tries of the South, is no doubt an enduring aspiration of all nations but environmental concerns, pollution, environmental degradation, carbon emission, climate change with the possible eventual in-hospitability of the earth for humanity, had informed the concept of sustainable development. The UNEP Report "Our Common Future" (Brundtland, 1987) defines sustainable development as "Development that meets the need of the present without compromising the ability of the future generations to meet their own needs" (Brundtland, 1987: p. 5; Adams, 2001). Sustainable development ideals must now be a philosophical spine that must guide the exploitation of mineral resources if humanity is not to come to climatic self-induced ruin. To ascertain the readiness of the Nigerian legal regime for the avoidance of environmental disaster prior to and during exploitation of bitumen and assure sustainable development in the bitumen sector of the country, this study takes a critical look at two important environmental statutes, namely the Environmental Impact Assessment (EIA) Act and the National Environmental Standards and Regulations Enforcement Agency (NESREA) Act. Attainment of sustainable development in the natural resource sector has gone beyond a national policy aspiration, but has become an international normative demand for all countries in bid to ensure an earthly environment with minimal pollution (UNDESA, 2015).

The exploitation of bitumen in Nigeria has become a key government economic strategy in the diversification of Nigerian economy as it is one of the solid minerals the Nigerian government intends to fully develop (Fayemi, 2015). Due to the industrial outlay of the mining technology for the processing of bitumen and the potential for huge environmental disruption, there is need for laws and regulation specifically enacted to suit the unique nature of bitumen as a sand/clay embedded with hydrocarbons (Akinsulore, 2017-2018). In order to ensure sustainable development in the exploitation of this resource, strict monitoring of the impact of bitumen must be conducted prior to development and during the active period of exploitation to avoid envisaged environmental problems (Milos, 2015). The likely environmental impact of bitumen will also affect the socio-cultural activities of the community members living in that bitumen area, thereby instigating social unrest (Chindo, 2015). Dissatisfaction with extraneously induced poor environment will translate to a loss of social license to operate for the extractive industries (Nwapi, 2016). There is therefore a need to ensure that the environmental laws in place for bitumen region are adequate to forestall these challenges. The analysis of the laws mentioned above is to ascertain their inherent capacity to assure sustainable development of bitumen in Nigeria. This paper proceeds with the jurisprudence of sustainable development after the introduction. Thereafter, a critical appraisal of the EIA Act and the NESREA Act is done with the aim determining how the provisions of the laws have made suitable rules for the exploitation of bitumen. The paper concludes with suggestion. 


\section{Theoretical Background: Sustainable Development}

\subsection{Development}

The term development has been ascribed with different meaning depending on the context that informs the interpretation. While development has been conceived from a rights point of view (Udombana, 2000), other opinions have seen it as a pursuit of wealth creation under the guardianship and control of the state (Myrdal, 1968; Kanbur, 2018). State intervention in market development is anathema for those who believe that for a sustained long term development, market forces should be allowed to play-out without the meddlesome influence of state intervention (Berend, 2006). For the time being the interpretation adopted is that development is a socially planned rational and sustainable use of natural resources to satisfy the needs of the populace in a nation. In addition, access to basic services are not denied to social groups that make up the populace while their cultural and traditional uniqueness are accorded their due respect and allowed to flourish within the social framework of each country (Reyes, 2001).

Development which traditionally is often an economic and social goal is also conceived as a process to restructure the socio-economic system of a nation (Lord, 2019). Development has been equated with human freedom as it involves "...the removal of major sources of unfreedom" in a way that they are able to fight "economic poverty", social deprivation, etc., which have denied citizens of their basic physiological, social and political needs (Dare, 2009; Anand \& Sen, 2007). The purpose of development, in the view of some scholars, is "to enlarge people's choices" at the financial, epistemological, nutritional and socio-cultural levels so that they can "enjoy long, healthy and creative live" (Haq, 2006; Prendergast, 2005).

Anand and Sen suggest that development can be seen from the "Conglomerative perspective" which is characterised by assessing the progress being made by different groups in the society putting weight on the "fortunes of the rich as well as the poor, the well-provided for as well as the deprived" (Anand \& Sen, 1997). There is also the "deprivation perspective" wherein the concern is specifically on those who are forced to live deprived lives (Ibid). From this deprivation perspective, failure to reduce the disadvantage that has kept the deprived in their position cannot be overcome by advances made by better-off people. Even while everyone needs to be counted and taken care of as it would go against the right of each citizen not to be accounted for, whether rich or poor, the public concern always tilts towards the advancement of those who are less privileged and forced to live reduced lives (Ibid, 2).

\subsection{Sustainable Development}

The Brundtland Report highlights the major socio-political changes that sustainable development implies. These include poverty elimination, equality in global resource distribution, population control, appropriate technology, lifestyle changes, effective democratization through increased citizen's participation 
(WCED, 1987; Baker et al., 1997). Susan Baker expatiates further that sustainable development as espoused in the Brundtland Report is promoted as an agent of social change through three interfaces: the social, the economic, the ecological (Baker, 2006). Baker opines that sustainable development being an "on-going" process with "desirable characteristics" that change over time depending on the locational, historical, political and cultural contexts, it would be more appropriate to conceive sustainable development as a concept to "promote" rather than achieve (Ibid, 8).

The three-pillar model of sustainable development has been faulted (Dawe \& Ryan, 2003). It has been argued that placing the environment in the same pedestal with economic and social concern is faulty logic as the environment founds the basis for any economic or social wellbeing achieved by man. It is asserted, quite forcefully, that environment is the "floor upon which the stool of sustainable development must stand" (Ibid). Since the environment sustains the economic and social wellbeing of man, it stands to reason that the environment cannot be a stool in the pillar of sustainable development. Rather it must be considered exogenous and at a more significant level than either the economy or social well-being of humanity. (Ibid)

Bridging the gap in the scheme which focuses on the way and manner the needs of the poor will be fulfilled and curtailing the wants of the rich is the focus of the Brundtland Report (Baker, 2006: p. 20). It is now an acceptable realisation that the high consumption rate of the industrialized world can no longer be sustained by the earth's ecosystem and therefore it is high time reduction be brought to the rapacious consumption in the global North to allow for even utilisation of ecological provisions for every person on earth particularly those in the global South where the higher percentage of the world's poor reside. Therefore, Nayar argues that sustainable development remains an inequitable conceptual schema between the advanced country of the North and the developing ones in the South and that the starting point for sustainable development is the reduction in the consumption and polluting capacity of the advanced countries which has damaged much of their environment and that of the developing countries where they source for resources. Therefore, the political dynamics of sustainable development is "anti-poor, anti-south and thereby anti-ecological" (Nayar, 1994).

The Bruntland's definition of sustainable development evinces normative values: values of equity and justice. Intergenerational equity that ensures that the needs of all, specifically the poor, are met; that poverty is eradicated in the developing world; that access to energy does not distinguish the rich from the poor and that impractical renewable energy source is not forced on the poor countries (Njiro, 2002). However, sustainable development is said to have a contested meaning being a "notoriously slippery and elusive concept" (Williams \& Millington, 2004). The definitional diversity is often competing and frequently opposing (Baker et al., 1997: p. 8). Two ideological beliefs can be said to be the 
philosophical underpinning of sustainable development. These are the "anthropocentric" and the "ecocentric" positions. Ecocentricism is nature centred and it is based on the view which emphasises balance between the needs of man in the exploitation of nature and other living things that get their sustenance from nature. The anthropocentric view is centred on humanity such that nature is of value only to the extent that wealth can be created from it to satisfy human wants. In fact this view represents a Judeo-Christian conceptualisation of the connection between humanity and nature which proclaims humanity's God-given right to dominate all things on the terrestrial for their replenishment and growth (Holy Bible, 2003). Anthropocentricism asserts, confidently, that environmental problems that may have emanated from mankind's conquest of nature can be ameliorated by technological progress. Technology will allow humanity to be able to manipulate the earth to meet their enormous demands (Achterberg, 1993).

What defines theorists who interpret sustainable development from an anthropocentric point of view is that their conceptualisation of what economic development and progress entail remains unchanged and rooted in the use of nature to benefit of man only (Williams \& Millington, 2004: p. 101). Accommodation of environmental concerns is only within the confines of developing techniques that would use resources efficiently and creating environmental agencies that would monitor that efficiency levels are not compromised.

There are others with ecocentric interpretation of sustainable development (Ibid, 102). They are of the view that anthropocentricism is geared towards "sustaining development" rather than sustaining nature or its life support systems on earth. They argue that nature has a right not to be molested and it does not require human justification (Ibid).Anthropocentricism is replaced by "bio-centric egalitarianism" which means the equitable recognition of non-human rights (Ibid).

The dichotomy between anthropocentricism and ecocentricism was principally an issue in the countries of the developed North. Traditional African practice of nature exploitation has always been characterised by balance and sustainability between the needs of man and the health of nature (Achebe, 2012; Eyo, 1990). Hence nature, for example, is cloaked in myths of super-human strength with capacity to make or mar human desires and indeed human existence (Alao, 2015). Nature is deified such that exploration of nature is often preceded by an apotheosized grant of the human request (Raji \& Abejide, 2013). However, the wholesale embrace of western industrial practices that is steeped in anthropocentricism by African countries has disrupted, stunted that indigenous practices of balanced and sustainable exploitation of nature.

Sachs and Maennling's position is that in promoting the sustainable development goals, resource rich countries have to leverage extractive sector linkages not just to promote diversification but also the Sustainable Development Goals (SDGs) (Sachs \& Maennling, 2015). They are geared towards a sustainable economic development agenda that is environmentally responsive, equitable and socially inclusive (UNDP, 2019; Sonesson et al., 2016). Meeting the SDGs will 
require unprecedented cooperation and collaborations among all stakeholders which will include government, NGOs, development partners, the private sector and the community.

The ideals of SDGs must also be incorporated into the practice and procedure of these stakeholders. This is particularly so for mining industries and the community where the resource extraction is taking place. Sonesson et al. narrowed their attention to some of the SDGs where the nature and scope of mining activities can create opportunities and leverage. ${ }^{1}$ (Sonesson et al., 2016: p. 5) This makes the mining industry and the mining sector an important player in the achievement of SDGs. Mining companies must therefore be ready for the task of development. They must be ready to "integrate changes into their core business and...bolster collaboration and partnership with government, civil society, communities and other stakeholders." (Ibid).

Commercial exploitation of resources endowment of countries of the south still provides an attractive means of getting out of underdevelopment. Inevitably, ecosystems will be disturbed, bio-diversity compromised in the pursuit of this economic goal. However, developing countries, especially in Africa, can adopt the two points of view in achieving sustainable development. What is needed is balance in the approach to implementing developmental plans which takes into consideration the need to apply nature resources to satiate human needs but a very strong monitoring and control of environmental practices of the participants in the economic endeavours. This balanced approach to sustainable development is recommended to be adopted for the exploitation of bitumen in $\mathrm{Ni}$ geria. After all, the indigenous African knowledge of nature has always emphasised balance in exploitation.

\section{Sustainable Development of Bitumen and the Nigerian Constitution}

The commercial exploitation of bitumen in Nigeria and the financial and economic upside provide an avenue for concept of modern development to be realised in the country. It opens opportunity for job creation, technology transfer and development of capacity in areas such as conversion technology, environmentally friendly recycling technology, highly advanced conservation management techniques which are hallmarks of the industry in advanced countries such as Canada (Akinsulore, 2017-2018: p. 224). Sustainable development requires healthy environment which bitumen development may obviate if dynamic and robust environmental laws and regulations are not put in place. Healthy environment is essential for well-being of human beings and as such activities that might tip the balance of a healthy environment has been of great interest in modern times. The Nigerian Constitution guarantees that government will provide a healthy environment for its citizens albeit such rights are unenforceable by the citizens in the court of law as this section of the constitution are

${ }^{1}$ SDGs $1 ; 6$ \& $15 ; 7 \& 13 ; 8 ; 9 ; 16$. 
non-justiciable. ${ }^{2}$ The need to integrate good environmental practices alongside development was recognised and given firm footing at the international level in the Brundtland Report of 1987 (Brundtland, 1987). National governments were given impetus to incorporate environmental considerations into multi-level decision making through the 1992 UNED Earth summit ${ }^{3}$, the Rio Declaration ${ }^{4}$ and Agenda 21 (Tetlow \& Hanusch, 2012).

The pressure for development through exploitation of natural resources must be balanced with active steps that mitigate impact of exploitative activities on the environment and in turn the capacity for human existence. The Brundtland Report makes sure to present sustainable development as an integrated strategy that looks not only at the environment but also at development. Importantly too is the need, as clarified recently by Gro Brundtland, to carry along the poor developing countries in the sustainable development agenda and make sure that the dialogue does not shot out their developmental concerns:

We can't neglect that and turn only to environment and also there could never be a global consensus on environment if poor countries felt that this would stymie them from closing the gap with rich countries (Brundtland, 2020).

For Brundtland, carrying out the sustainable development agenda is not just about protecting the economy of countries nor their environment but also “...defending justice, preserving human rights, and committing to social solidarity" (Brundtland, 2018).

The development of bitumen resources provides opportunity for a developing country like Nigeria to breach this gap as noted by Brundtland above. It provides avenue for economic diversification for the country, capacity building and technology transfer (Akinsulore, 2017-2018: p. 224). However, the exploitation of bitumen has been recognised to have adverse footprint on the environment if not strictly monitored (Weinhold, 2011; Jordaan, 2012). It is therefore necessary to engage some specific aspect of existing legal and regulatory framework for the protection of the environment within Nigeria so as to ascertain whether their provisions can guarantee strict monitoring of the bitumen exploitation activities that would align with the tenets of the sustainable development.

In considering the constitutional foundation of environmental protection, section 20 of the Nigerian Constitution appears to have given a firm root to environmental protection as it declares the protection and improvement of the environment as an obligatory duty of government. The snag, however, is that the duty is placed within Chapter II of the Nigerian Constitution making it unjusticiable by virtue of section 6(6) (c) the same Constitution which oust the jurisdiction of Nigerian courts from considering questions which challenge the state on

\footnotetext{
${ }^{2}$ See section 20 of the Constitution of the Federal Republic of Nigeria, 1999.

${ }^{3}$ It was held in Rio de Janeiro Brazil 3-14 June 1992.

${ }^{4}$ Rio Declaration on Environment and Development was the documentary outcome of the Rio Earth Summit in 1992.
} 
the fulfilment of such duty captured within Chapter II of the Constitution.

It is further observed that environmental protection is not encoded in a precise constitutional legislative listing as it is neither in the Exclusive nor the Concurrent Lists of the Nigerian Constitution. ${ }^{5}$ The only other option for legislative intervention on environmental matters is to interprete that matters on environmental protection are in the Residual List, in line with the reasoning of the Nigerian courts. ${ }^{6}$ The Residual List has been interpreted by the Nigerian Supreme Court to be "what was left after the matters in the Exclusive and Concurrent Legislative lists and those matters which the Constitution expressly empowers the federation and the state to legislate upon have been subtracted from the totality of the inherent and unlimited powers of a sovereign legislature". The Court made further declaration that this is a judicial formulation to enable it exercise its "interpretative jurisdiction" in the face of constitutional silence and as a corollary to the above, the federal tier of government has no power to make laws on the matters in the Residual List. ${ }^{8}$ By implication, residual matters are located within the legislative competence of the state assembly. ${ }^{9}$

Ogbuabor has provided alternative interpretation to the conceptualisation of residuality within the Nigerian Constitution (Ogbuabor, 2014). He argues that based on the decision of the Nigerian Court of Appeal in the case of Egbuniwe $V$ $F G N^{10}$ and the Supreme Court decision in the case of Fawehinmi $v$ Babangida ${ }^{11}$ state assemblies do not have exclusive jurisdiction to exercise power over residual matters under the Nigerian Constitution because while some residual matters fall within the legislative competence of the state, others fall within the federation legislative competence. He contends that the convention that states have jurisdiction over residual matters in the constitution is "founded upon fiction rather than law or logic" (Ogbuabor, 2014: p. 274) and that by virtue of section 4(4) (b) of the Nigerian Constitution 1999, the National Assembly is open to legislate on residual matters as this section envisages that it is not every matter that the National Assembly has power to make laws on that will be on the legislative list (Ibid, 299).

While there is no doubt that Ogbuabor's arguments are robust, it obviates the important information that National Assembly's capacity to legislate on residual matter is anchored on the unique nature of the Nigerian Federal Capital Territory (FCT) which is run by the federal laws but recognised and cloaked with state powers under the Nigerian Constitution. ${ }^{12}$ Invariably, FCT, like any other state within the federation, is entitled to have jurisdiction over residual matters.

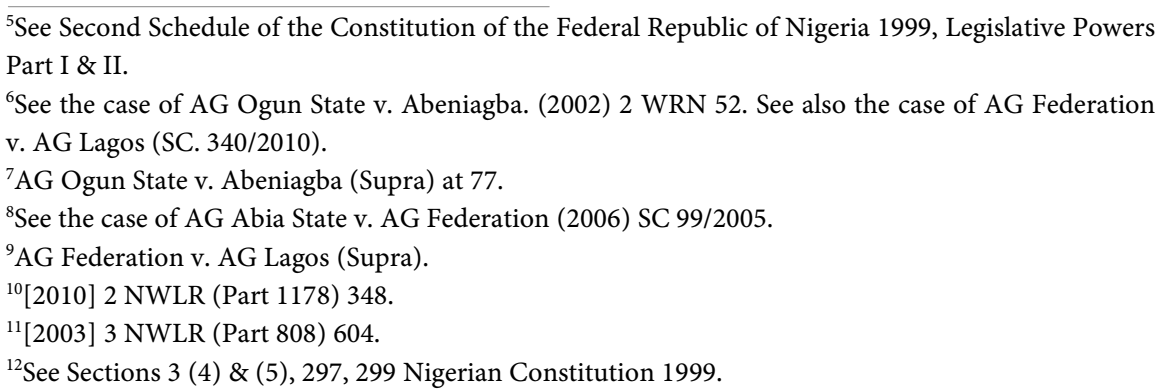


That is why in this case it is the National Assembly that exercises this residual power on behalf of the FCT being the arm of government that makes laws for the FCT. At any rate the argumentation of Ogbuabor is too narrowly fixated on the issues created by residuality of Tribunal of Inquiry created by the Nigerian federal government and the power of the National Assembly to make laws based on residual matters. It is opined that this is not enough to uncloak the States Assemblies of their power to have exclusive jurisdiction on residual matters as interpreted by the Supreme Court in the case of AG Ogun State v. Abeniagba.

Given that environmental protection is in the Residual List of the Nigerian Constitution, it could be assumed and indeed argued that the making of laws on environmental protection matters by the federal legislature is unconstitutional. This assumption would turn out to be wrong if the Nigerian Constitution is given a more critical look. A close look at the Constitution shows that federal government has jurisdiction over mines and minerals, including oil fields, geological survey and natural gas. It could therefore be argued that environmental matters relating to mines and minerals fall under the Exclusive List. Furthermore, environmental matter incidental to matters captured under the Concurrent List fall to both tiers of government, subject only to the doctrine of paramountcy ${ }^{13}$, and those that fall neither in the two lists come within the jurisdiction of the state legislature (Ingelson \& Nwapi, 2014). It would therefore be safe to conclude that matters relating to mines and minerals, including oil fields, geological survey and natural gas and environmental matters incidental to the exploitation of these natural resources come within the legislative competence of federal legislature. Laws made therefrom should be considered good law within the interpretation of the Nigerian Constitution. The important question that subsists is that given that environmental protection is key to the wellbeing of all persons living in Nigeria and that as a federation the welfare of citizens should be a concern of all the federating states, should there be an area of environmental concerns that restricts state participation in its regulation and control?

This study now proceeds to analyse two federal laws on the environment-the Nigerian Environmental Impact Assessment Act (EIA) and the National Environmental Standards and Regulation Enforcement Agency (NESREA). These two laws are important in the exploitation of bitumen because while the former is preventive and anticipatory in scope, the latter deals with the possible environmental fall out that had been envisaged by the EIA in such a way as to mitigate any environmental disruption and harm.

\section{The Nigerian Environmental Impact Assessment (EIA) Act and Bitumen}

One of the aims of sustainable development is to ensure a healthy environment through the implementation of preventive and predictive measures that forestall environmental pollution in the activities of extractive industries in their quest to

\footnotetext{
${ }^{13}$ Section 4 (5) the Nigerian Constitution 1999.
} 
engage in economic activities by resource exploitation. ${ }^{14}$ As desirable as development is for humanity, it comes with its side effects some of which are environmental in the form of disruption of landscape, loss of biodiversity, pollution etc. In order to reduce the impact of these developmental projects, environmental planning tools such as the Environmental Impact Assessment (EIA) report are introduced with the aim of providing information to decision makers which will help them factor environmental protection into their decision making process "prior to approval, rejection or modification of proposed project plans or activities" (Olawuyi, 2015). Hence the enactment of Environmental Impact Assessment (EIA) into law as part of the governance regime that regulates extractive industry activities is aimed at achieving sustainable development in the natural resource sector of a country's economy. This law is an attempt by Nigeria to comply with international best practice on the environment and enthronement of sustainable development (Etemire, 2014).

There are opposing interests to be balanced. On the one hand there is the interest of the developer and government who are interested in the economic benefits of the resource exploitation. On the other hand, there are the interests of the host community (or the public) who by virtue of proximity to the resource environment are naturally concerned about the environmental effects resource exploitation will have on their lives and livelihood (Ojobgo, 2018).

EIA has international anchorage found in international instruments which many countries of the world have subscribed to. Thus for example, the World Charter for Nature provides for the use of best available technologies to minimise the adverse effects of human developmental activities on nature. ${ }^{15}$ Also, there is the United Nations Environmental Programme Goals and Principles of Environmental Impact Assessment which are recommended guidelines for the issuance of environmental impact assessment (UNEP, 1987). Furthermore, the Convention on Biodiversity (CBD), in order to avoid or minimise effect resource exploitation, enjoins on parties the introduction of procedures requiring environmental impact assessment of proposed project likely to have significant impact on the biodiversity. ${ }^{16}$ It also allows public participation in this process Finally, the Convention on Environmental Impact Assessment in a Transboundary Context provides comprehensive provisions on the obligations of parties at an early stage to the environmental assessment processes (CEIA, 1991).

The aim of the Nigerian Environmental Impact Assessment Act (EIA Act) is to establish, before a decision is taken whether a project intended to be carried out by a person, federal state or local governments is likely, to a significant extent, have environmental effects ${ }^{17}$; to promote the implementation policies that are in line with environmental protection and to encourage information ex${ }^{14}$ See SDG 8 (Decent Work and Economic Growth); SDG 9 (Industry, Innovation and Infrastructure); SDG 15 (Life on Land).

${ }^{15}$ Article 11 (a)-(c) World Charter for Nature 28 October, 1982, A/RES/37/7, UNCHR. http://unhcr.org/.

${ }^{16}$ Article 14, Convention on Biodiversity (1993). https://www.cbd.int.

${ }^{17}$ S. 1 (a) EIA Act 1992. 
change among government organs and persons on the proposed projects that may have environmental effects. In summary EIA serves three purposes namely integration of environmental concerns into planning and decision making; Environmental damage limitation through anticipation and minimization and; Public participation in decision making. ${ }^{18}$

The Act provides that no project (under the mandatory list) shall be carried out by the by any individual, the private of public sector without prior consideration of the environmental impact of such a project-bitumen will fall into this category judging by its industrial outlay necessary for exploitation ${ }^{19}$ (Banerjee, 2012). The information generated by the project proposer shall be for the consideration of the government agency only. However, the public are not given opportunity nor are the project proposers legally mandated to allow inputs to the EIA report until a draft of the report is provided by the project proposer but prior to final decision taken by the Agency. ${ }^{20}$

The EIA Act provides for a seven-staged procedure for the execution of an EIA. These stages comprise project proposal ${ }^{21}$; screening ${ }^{22}$; scoping $^{23}$; EIA report draft and review process ${ }^{24}$; EIA final report ${ }^{25}$; decision making ${ }^{26}$ and; project implementation. ${ }^{27}$ The first stage is triggered by the submission of a project proposal by the proponent to the Federal Ministry of Environment. Relevant documents such as land use map and other useful information are attached to the proposal (Ingelson \& Nwapi, 2014: p. 46). The ministry responds by issuance to the proponent a guideline that would facilitate the EIA process. In order to determine whether the project is one which an EIA is mandatorily required or whether EIA is exempted, the screening stage (which is the second stage) is commenced. It is opined that given the invasive nature of bitumen extraction on the environment, it is unlikely that exemption will apply to a bitumen project.

At the third stage, the project proponent proceeds to map out the scope of the intended EIA when a determination has been made by the Ministry that the EIA is one designated as required under the law. At the fourth stage, a draft EIA of the proposed project is submitted by the project proposer to the Ministry for review (Ingelson \&Nwapi, 2014: p. 47). Mediation, public hearing and locus visitation are the varied methods by which the Ministry carries out its review. Review comments from the Ministry shall be transmitted to the proponents within sixty days of the receipt of draft EIA by the project proponent. Submission of final EIA report is at the fifth stage. ${ }^{28}$ The sixth stage comprises the approval process

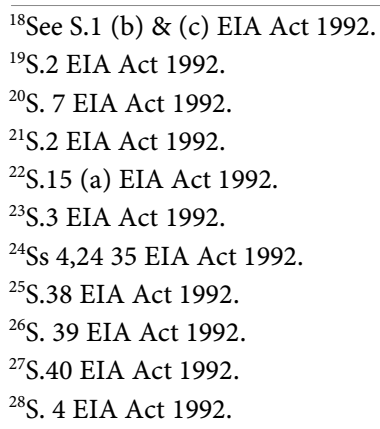


for the final EIA report the proposed project. This is the stage where members of the public, interested groups, experts in relevant disciplines are given opportunity to comment on the EIA report. ${ }^{29}$ Implementation of the EIA report is the final stage of the EIA procedure. There is an expectation that the project proponent begins to implement the EIA as approved by the Ministry while the latter monitors the progress of the implementation to ensure compliance.

Sustainable development in environmental matters is enhanced by public participation as emphasised by Principle 10 of the Rio Declaration. While sustainable development may not have specific constitutional provisions in Nigeria, the enactment of the EIA Act could have been an opportunity to give effect to the general environmental provision in section 20 of the Nigerian Constitution (Okon, 2016). EIA has been identified to be a useful tool in achieving sustainable development in environmental matters as it allows for "mainstreaming environmental concerns into development process" (Owoyemi \& Bamigboye, 2013). The Nigerian EIA Act has however bee severely criticized for not encouraging public participation in the EIA process (Etemire, 2018). As a matter of fact, the public or interested group is barred by the EIA Act from subjecting the acts or omission of the project planner to judicial review. ${ }^{30}$ The Act is also restrictive on the application of the "civil/private legal right" standing rule on matters brought under the Act. The view has been held that public participation in environmental matters has no judicial precedent to reiterate that it is legally enforceable in Nigeria (Ako, 2006).

Furthermore, participatory provisions in the EIA Act are subject to the "unguarded discretion" of government agencies (Etemire, 2018: p. 569). The Act has also been rendered weak and inefficient by the unreasonably wide exemptions accorded to relevant government agencies in the observance of the Act. Section 14 (a) and (C) of the Act gives such exclusionary powers to the President or the Council of the government agency to avoid the application of the EIA Act where the President or the agency is "of the opinion that the environmental effects of the project are likely to be minimal" or "the project is in the interest of public health or safety" (Ibid)

The exclusionary clauses, it has been opined, only provide "loopholes" for government and resource developers from compliance with the Act, a whim which goes to weakening the legal framework enacted for the sustainable development of natural resource and protection of the environment (Omorogbe, 2002). It is important to note that in environmental matters, public participation in decision making has been identified to engender high quality decisions that, ultimately, ensure sustainable development that protects the environment and guarantees the wellbeing of the human existence within it (Etemire, 2018; Anderson, 1998). In addition, a fundamental component of democracy is direct public participation in governance and this is where public participation in environmental decision fits into democratic practices (Etemire, 2018; Pring \& Noe, ${ }^{29}$ S. 7 EIA Act 1992.

${ }^{30}$ See S. 57 EIA Act 1992. 
2002).

The rights to receive information, express opinion and participate in political processes are values anchored in regional and international human rights instruments (Ojobgo, 2018: p. 38). The Nigerian EIA Act is, however, not a reliable regime to realise the concept of public participation. This is as a function of the inefficient justice system in the country which de-incentives participation of the public or interested group in the EIA process (Ibid). Even if it is argued that the right to environmental participation is enshrined in the Nigerian Constitution, it has been criticised that placement of participatory right in section 14 (2) (c) in Chapter II (a non-justiciable part of the constitution by virtue of section 6 (6) (c) of the Constitution) of the Nigerian constitution is "a deliberate downgrade" of the status of this participatory right (Etemire, 2018: p. 576).

A contemporary option to cure the lacuna in the EIA Act is to amend it in line with the Aarhus Convention. ${ }^{31}$ Although Nigeria is not a signatory to the convention, it has been argued that where it becomes unjustifiable for government to claim adherence to a deficient law, such a government are held accountable by right activists to "better laws" on the environment operational elsewhere such as the Aarhus Convention (Etemire, 2014: p. 156). Such amendment in the EIA Act, it has been proposed, should align with the three pillars upon which the Aarhus Convention relies on which are public access to environmental information, public participation in environmental decision making and access to judicial and administrative redress ${ }^{32}$ (Nwapi, 2008: p. 18).

In terms of public participation in environmental decision making, the EIA Act imposes no legal requirement on project proponents to engage affected public in their assessment before submitting the report (Ingelson \& Nwapi, 2014: p. 50). The later involvement of the public in the EIA process has been described as "an attempt by government to justify an act that is already completed." ${ }^{33}$ The exploratory nature of an EIA demands early public involvement in the process so that useful information that may affect the public may be properly and promptly inputted in the report when it is produced (Ingelson \& Nwapi, 2014: p. 52). In line with the above reasoning, the recent inauguration of a nine-man technical committee by the Irele Local Government Chairman, Ondo State Nigeria to "understudy and review" the EIA Report prepared by the Federal Ministry of Environment in relation to the environmental and social impact of bitumen exploration and exploitation in the local government amounts to an exercise to in futility as the EIA Report is already a fait accompli (Ikale Voice News Report, 2020).

Furthermore, in terms of access to justice and administrative redress, the EIA Act makes no provision for appeal of the decision approving an EIA report. This gap shields the approval from impartial judicial test. Other institutional problem

\footnotetext{
${ }^{31}$ The UN Economic Commission for Europe (UNECE) Convention on Access to Information, Public Participation in Decision Making, and Access to Justice in Environmental Matters 1998.

${ }^{32}$ See Articles 4, 5, 7 \& 8 of the Aarhus Convention.

${ }^{33}$ See also S.7 EIA Act 1992.
} 
confronting the agency is a lack of skills and facilities to carry out its regulatory functions. Furthermore, a profusion of authorities in the environmental sector created with similar roles and an absence of clear line of regulatory authorities creates confusion in the EIA process.

A comparative study of EIA process in the developed country and Nigeria provides a good summary of the deficiencies in the process in Nigeria which includes (Owoyemi \& Bamigboye, 2013: p. 219): misinterpretation and inadequacies of regulations which occasion delay in the EIA execution; duplication and overlapping of responsibilities by government agencies in the execution of EIA; effective sanction is absent; lack of awareness of the EIA provisions among Nigerians which then occasions inability to raise proper objection to projects perceived to be injurious to their environment within the statutorily required time frame; lack of transparency and credibility as well as exclusion clause abuse in the EIA Act (Ibid; 220).

Developed countries actively involve all stakeholders in the early stages of EIA but there is limited involvement of the public and government agencies at the initial phase of the EIA in Nigeria. Furthermore, screening practices is weak in Nigeria and it involves only the federal ministry of environment and its internal mechanism for determining which category of activity requires EIA. Whereas, in the $\mathrm{EU}$, for example, competent authorities do not come to a conclusion as to need for an EIA until after consultation with developers, NGOs and statutory consultees. In Nigeria, scoping process follows a term of reference which guide consultants that carry out the scoping and submit report to designated public officer. In developed countries, scoping process is comprehensive and it involves multi-layers of consultation with all identified stakeholders. The involvement of the public is actively sought and the scoping exercise is targeted to address their concerns (Ibid, 221).

Furthermore, EIA reports are not published in other indigenous language other than English in Nigeria as opposed to what obtains in developed countries where most reports are in local language. In the developed countries, there is alternatives to EIA and these are given proper consideration while this is absent in Nigeria (Ibid). EIA is approached from a multi-disciplinary approach in developed countries as experts in different areas are involved. In Nigeria, EIA are carried out by consultants who may or may not comprise multidisciplinary teams. Finally, there is poor implementation and monitoring of the EIA in Nigeria as public participation in monitoring is not compulsory.

Projects proposed for bitumen exploitation will have to use the extant EIA processes with all its teething problems identified so far. Already, the signs are not good as community stakeholder in the bitumen region have started complaining about ignorance of the exploratory activities of bitumen companies as they have neither been carried along nor do they have necessary information about the likely impacts of the proposed bitumen projects in their community. Monarch and chiefs in the Ode-Aye and Okitipupa LGAs Ondo State Nigeria, a 
significant bitumen zone of the country, have been recorded to express displeasure at lack of communication from the mineral title holding company on the impact of their exploitative activities on the community and the possible ameliorative measures that may be put in place even as they are willing to talk (Ojo \& Olufemi, 2004).

Furthermore, while the EIA mentions and recognises in specific terms the mandatory nature of EIA in the oil and gas sector ${ }^{34}$, there is no specific provision for the bitumen other than its categorisation under the rubric of mining. ${ }^{35}$ The lack of reference to bitumen in the EIA Act makes opaque any directives that might be given to the development of EIA reports to be generated by proponents intending to mine bitumen in Nigeria. It is opined that due to the likely high environmental impact bitumen exploitation would have on the resource environment, the EIA Act should be amended to include detailed provisions on bitumen as a guide to a more robust EIA report on the sector. In this wise, there will be need for EIA report on modes of bitumen extraction (mining or in situ techniques) (Speight, 2016); the processing and upgrading facilities and their siting; the appropriate design of pipeline needed to transport liquefied bitumen and impact of leakages on the environment (Banerjee, 2012; Watmore, 2013) and the refining facilities.

\section{National Environmental Standards and Regulation Enforcement Agency (NESREA) Act and Bitumen Exploitation}

The economic exploitation of bitumen brings with it physical activities at the resource sites which naturally affects the physical environment, alters the biodiversity and human lifestyle. It is therefore very important that care should be taken that the environmental impact of bitumen, which has been identified as being potentially significant (Grant et al., 2013) be mitigated and controlled. Bitumen, under Nigerian law, is a solid mineral and therefore comes under the coverage of NESREA for the monitoring and enforcement of environmental laws and regulations.

Historically, Nigerian environmental laws and regulations, particularly after independence, have been premised on an ideology of national economic development and provision of basic amenities such that environmental concerns were give less priority as it threatens the national plan to industrialise (Ogunba, 2016). The toxic waste environmental pollution occurrence in 1988 at Koko, Delta State (UNEP, 2018) Nigeria changed the economic advancement ideology model and led to the establishment of the Federal Environmental Protection Agency (FEPA), the precursor agency to the establishment of NESREA. FEPA has as its underlining objective sustainable development founded on the proper management of the environment to meet the need of Nigerian citizens, present and fu-

\footnotetext{
${ }^{34}$ See parag. 12, "Mandatory study activities" of the Schedule to the EIA Act 1992.

${ }^{35}$ Parag. 11 "Mandatory study activities" of the Schedule to the EIA Act 1992.
} 
ture (Ogunba, 2016; Egunjobi, 1993). The 1999 Constitution of the Federal Republic of Nigeria makes provision, for the first time, on environmental protection which previous constitutions never did (Nwauzi \& Fab-Eme, 2019). Save for the FEPA Act which it repeals, the NESREA Act is not enacted to supplant existing statute but rather through its established agency centralise the enforcement of environmental statute while also empowered to make further regulations for the preservation of the Nigerian environment (Stevens, 2011).

The NESREA $\mathrm{Act}^{36}$ created an agency with environmental protection and maintenance, sustainable development of the Nigerian natural resources as its primary mandate. The Agency is clothed with wide powers under the law with its primary responsibility being the enforcement of compliance with national and international laws, guidelines and standards in all sectors other than the oil and gas sector ${ }^{37}$ (Amokaye, 2014; Olawuyi, 2015). This enforcement of compliance strategy deployed in NESREA is opposed to standards and regulation enumeration which operated under FEPA (Adeoluwa, 2018).

The agency is given the authority to monitor and enforce compliance with national and international laws on the environment which is to be achieved through monitoring and regulatory measures. ${ }^{38}$ It is also conferred with the power to review regulations of air and water quality, harmful substances and effective limitations. ${ }^{39} \mathrm{~A}$ broad suite of management and compliance verification processes are deployed by the agency to secure compliance with local laws on environment. These include Environmental Impact Assessment, standard setting, litigation, negotiation, incentives and disincentives, inspection and verification processes, incentivizing internal self-regulation through a process of environmental audit and management (Amokaye, 2014; Okorodudu-Fubara, 1998). In the exercise of powers conferred on it by the law, the agency has promulgated thirty three (33) regulations covering quite a number of environmental and natural resources area but significantly no regulation has been made for the bitumen sector (NESREA Laws and Regulations, 2020).

A significant identified shortcoming of NESREA Act is its exception of the oil and gas sector from its sphere of operation and regulation. ${ }^{40} \mathrm{With}$ the exception, the agency cannot extend its powers of public investigation, review of regulation and standards, guidelines related to the oil sector. ${ }^{41}$ This exception is particularly significant for bitumen exploitation as it excises from NESREA's monitoring capacity the complete refining process of bitumen. The refining process of bitumen which coalesces into the petroleum is thereby removed from the holistic and complete coverage, review, monitoring of the environmental impact of bitumen by NESREA. The Act does not envisage nor make provisions for natural

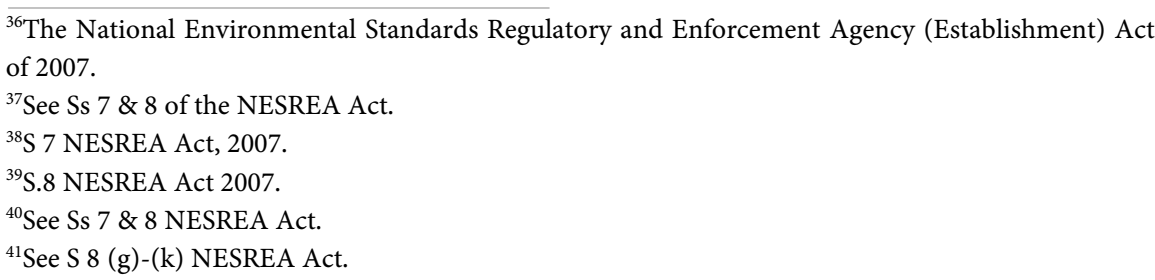


resources which combine the attribute of solid minerals and that of hydro-carbon components.

Another envisaged challenge with the current status of environmental laws in Nigeria is the inter-agency cooperation between NESREA and the National Oil Spill Detection and Response Agency (NOSDRA) ${ }^{42}$ as they have to monitor the environmental footprint of bitumen which is very key to the avoidance of bitumen related pollution. As it stands, there are no clear lines of regulatory demarcation as to when bitumen environment issue will come within the jurisdiction of NOSDRA. The above challenge is not linear but there are other legal issues with a successful monitoring of a bitumen environmental footprint given the current status of laws in Nigeria. For one, the Nigeria Petroleum Act does not recognise bitumen as oil or its derivative and as such bitumen related environmental pollution is not captured within the extant legal and regulatory frame work for the oil and gas sector which already has a developed infrastructure for the transportation and refinement of petroleum and indeed hydrocarbons. ${ }^{43}$ In fact, the Oil Pipeline Act disallows the transportation of any other form of liquid through the oil pipeline other than mineral oils, natural gas or any other derivatives used or intended to be used in the production or refining of mineral oil, natural gas or any other of its derivatives. ${ }^{44}$

The dichotomy created by the exclusion of the oil sector from environmental monitoring by NESREA and the creation of other speciallised agencies to cater for the oil and gas sector, such as NODSRA, is likely to negatively impact on efficient monitoring of bitumen environmental footprint. Apart from a recognised sparse inter-agency cooperation in Nigeria's extractive sector (Olaniyan, 2015), there is the possibility of continued encouragement of enclave system of infrastructure development among mining industry thereby obviating the need for the development of a shared-use agreement among these industry players in the extractive industry (NRGI, 2015). The implication on bitumen exploitation of these resource specific exclusive laws is that it disallows provisions for multi-user infrastructure base which take advantage of economy of scale and predictability of environmental impact in the event of pollution (Ibid, 3).

The exception of the oil and gas sector from the environmental coverage of NESREA has been considered a "monumental" inhibition to the work of the agency such that its institutional capacity to conduct public investigation on pollution and degradation of natural resources cannot be said to be robust and encompassing (Mmadu, 2013). Furthermore, NESREA cannot enforce hazardous waste regulation in the oil and gas sector. Neither can it "monitor, license, research, survey, study or audit the sector." It cannot also promote compliance nor seek for environmental regulation evolution in the oil and gas sector (Stevens, 2011: p. 397). There may be a problem in these restrictions on the

\footnotetext{
${ }^{42}$ Established under the National Oil Spill Detection and Response Agency Act, 2006 (NOSDRA Act).

${ }^{43}$ See S 15 of the Petroleum Act Cap P10 Laws of the Federation of Nigeria 2004.

${ }^{44}$ See Ss 4 \& 11 (2) of the Oil Pipeline Act Cap 07 Laws of the Federation of Nigeria, 2004.
} 
NESREA when it comes to monitoring compliance in the bitumen industry. The reason being that in the industrial production process of bitumen (from transportation of the bitumen to the refining stage), it comes to a stage where there is capacity coalescing into the oil and gas sector. Monitoring of hazardous waste over the processing chain with such legal restriction on bitumen is unwholesome for the bitumen sector. In addition, the exclusion of the oil sector from the coverage of Nigerian environmental laws has constrained NESREA from effective monitoring of oil production on biodiversity (Olawuyi \& Olusegun, 2018). It is opined that NESREA might suffer such constraint in the monitoring of the environmental impact of bitumen production when the bitumen production process (Mid-stream and downstream) necessarily coalesce with the oil sector.

By NESREA Act's definition, pollution is the "man-made or man-aided alteration of chemical, physical, or biological quality of the environment beyond acceptable limits." ${ }^{45}$ Where pollution thus occur through non-conformity with the law or regulation or through negligence by an actor in the environment, only public bodies such as NESREA can go to court for the enforcement of environmental law or regulation. ${ }^{46}$ Action to protect the environment is traditionally the confine of public authority. However, where an individual wishes to bring an action seeking redress to injury done to the public, the permission of the Attorney-General of the federation would have to be obtained (Okonkwo, 2018; Orji, 2012). The scope of private litigation is limited to seeking redress for private injury (Okonkwo, 2018: p. 128). In order words there is no provision under the NESREA Act for public interest litigation. Individuals, NGOs or local community lack the legal capacity or locus standi to bring claims for enforcement or compliance against a corporation that is in clear breach of an environmental law or regulation where NESREA fails to act (Chiwendu \& Osimiri, 2020).

In Nigeria the issue of locus standi has been a major impediment to the pursuit of environmental matters in court. The consistent holding of court on standing is that plaintiff can only benefit from it if he can show that "his civil rights and obligations have been or are in danger of being violated or adversely affected by the act complained of ${ }^{\prime 47}$ (Frynas, 1999). It is high time legislation is passed in Nigeria that confers locus standi on individual who may choose to institute action for the protection of the environment where threat exist on the environment or where there is actual environmental pollution without recourse to proving damage suffered (Fagbemi \& Akpanke, 2019).

A way out of this standing conundrum is to approach environmental matters from the human rights point of view. This entails entrenching a right to clean environment as a human rights in the Nigerian Constitution. At present, the Nigerian Constitution does not have explicit guarantee of the right to clean en-

${ }^{45}$ S.37 NESREA Act 2007.

${ }^{46}$ See Ss 1 (2) (a) \& 7 (a) NESREA Act 2007.

${ }^{47}$ Centre for Oil Pollution Watch v. Nigeria National Petroleum Corporation (2013) LPELR-2007 5(CA); Att. Gen. Kaduna State V. Hassan (1985) 2 NWLR (Pt.8) 483 SC; Social and Economic Rights Action Centre and the Centre for Economic and Social Rights (SERAP) v. Nigeria No. 155/96. 
vironment (Orji, 2012: p. 343). The right to clean environment needs to be included in the constitution as this will serve as a veritable means for public participation in the enforcement of environmental laws in Nigeria (Ibid, 344). Countries such as India and South Africa have entrenched right to clean environment as human rights into their constitutions. As Nigeria has relaxed access to court on fundamental human right cases by allowing interested parties to institute action on behalf of person(s) incapacitated, it is high time that the constitution is amended to a include the right to clean environment as one of the fundamental rights which can then be pursued without the toga of standing impeding such a cause (Fagbemi \& Akpanke, 2019: p. 34).

Furthermore, sustainable development should be infused into the right to life under the Nigerian Constitution as this will allow individuals, NGOs or Community to bring activities of corporations that threatens their environment and invariably their lives under the rubric of violation of fundamental rights provisions of the constitution (Chiwendu \& Osimiri, 2020: p. 152). At any rate, Article 24 of the African Charter on Human and Peoples' Rights provides a right to a general satisfactory environment favourable to their development and that since this Charter has been ratified and domesticated in Nigeria, it is arguable that the right of Nigerian citizens to enjoy satisfactory and favourable environment has become "crystallised" (Nwauzi \& Fab-Eme, 2019: p. 212). The unjusticiability of section 20 of the Nigerian Constitution can no longer obtain on this right.

NESREA enforces environmental control measures through registration, licensing and permitting systems, while penalties for infractions are limited to fines and imprisonment ${ }^{48}$ (Ladan, 2012). Creative sentencing devices as used in Alberta Canada can also be adopted in ensuring compliance with environmental laws and directing positive outcomes for stakeholders in the solid mineral sector of the country. Creative sentencing is based on restorative theory of justice and is applied in the context of environmental offences such that the damaged environment can be restored to the state it was before the offensive activity (Nwapi, 2015). In addition to the statutory penalty of fine or jail term, provisions on creative sentencing allows court to make orders which would entail offender channel fund to community affected by their act or the society at large or that the offender engage in acts that would go to ameliorating or "righting the wrong or tracing the cause of the offence" so as to ensure recurrence prevention (Ibid, 14). The adoption of creative sentencing, it is opined, will direct the attention of violators to adoption of a more sustainable resource exploitation that is environmentally friendly and at the same time affords industrial actors to participate in finding solution to the needed balance between commercial exploitation and environmental concerns (Sonesson et al., 2016: p. 43).

The opinion that the NESREA Act is a sincere, pragmatic law enacted for protection, preservation and development of the Nigerian environment becomes dented when it comes to the applicability of the law to bitumen exploitation ${ }^{48}$ See ss. 20(3) and (4), 21(3), 22(3) and (4), 24(4) and (5), 25(2) 26(3) and (4), and 27(3), (4) and (5), 31 and 37NESREA Act, which provides for Penalties in form of Fines/Imprisonment. 
alongside necessary environmental interventions (Nwauzi \& Fab-Eme, 2019: p. 209). The absence of a regulation on bitumen puts the emerging bitumen sector in an unacceptable, rudderless environmental situation that can be leveraged by unscrupulous corporate actors as long as this lacuna exists. For instance, enforcement of the criminal provisions of the Act is dependent on the establishment of a legal regulation on that aspect of environmental protection. Where the regulation is absent, the criminal liability cannot be established. ${ }^{49}$ For the bitumen sector, pollution activities that may occur by industrial actors would have no penal legal consequence. This is alarming and must be avoided as the pollution footprint of bitumen needs to be stringently monitored if greater disaster than the one witnessed in the Niger-delta region of the country is not to be re-enacted. It is therefore necessary that the Minister exercises his prerogative under section 34 of the Act to make regulation for this critical sector in order to give force to the provisions of the Act in the bitumen sector (Adeoluwa, 2018: p. 202).

\section{Conclusion}

In summary, this paper has shown that the Nigerian EIA Act will not engender sustainable development in the bitumen sector as it does not provide for public participation in environmental decision making before the EIA report is produced. The absence of legal requirement for project proponents to engage with affected community before submitting the EIA Report is also not encouraging. The failure of the EIA Act to specifically recognise the mandatory nature of the EIA report for the bitumen sector poses a threat to sustainability as it is then open to operator's interpretation and manipulation when undertaking the process of generating the report. Furthermore, the failure of the Minister to exercise his power to provide regulation for bitumen under the NESREA Act jeopardises the sustainable development of the resource in the country. This is because where there are no regulations, then criminal liability cannot be established against any person that infracts the law.

It is important to note that in order to avoid the serious environmental impact that can occur as a function of unsustainable development and exploitation of bitumen in Nigeria, more suitable laws and regulations must be put in place to prevent environmental decline and enthrone best practice and technology for the development of bitumen. It is apparent from the preceding analysis on two environmental laws in Nigeria that they suffer some inadequacy which will make the attainment of sustainable development in the bitumen sector of the country a mirage.

The EIA and NESREA Acts need to be amended in order to make it responsive to the specific needs of bitumen development. Therefore, it is recommended that stakeholder involvement in the preparation of the EIA Report should be commenced early rather than what obtains in the law at present. The EIA Report

${ }^{49}$ See S 36 (12) Constitution of the Federal Republic of Nigeria 1999. 
should also be communicated in indigenous languages of the country, particularly the language of the area where the impact of resource development will be most felt. This communication strategy will allow for better understanding between the mineral title holder and the resource community when exploitation commences as the community will already have an understanding of the nature of activity to take place and the manner it may like impact on their way of life and livelihood. Furthermore, the Minister for the Environment should exercise his power under the NESREA Act in expeditiously making regulations for the exploitation of bitumen as it does not exist hitherto. This regulation would guide the many aspect of bitumen processing and will go a long way in strengthening strive for sustainable development in the sector.

If Nigeria is not to repeat the environmental disaster occurring the Niger-Delta region of the country where petroleum is being drilled, then there is need to take proactive and strong measures which will show the application of the lesson learnt in the oil and gas sector deployed to use in the bitumen development in a safe, environmentally friendly and sustainable manner. To do otherwise is to invite unprecedented environmental chaos in the Nigeria bitumen region.

\section{Conflicts of Interest}

The authors declare no conflicts of interest regarding the publication of this paper.

\section{References}

Achebe, C. (2012). There Was a Country: A Personal History of Biafra (pp. 18-19). London: Allen Lane.

Achterberg, W. (1993). Can Liberal Democracy Survive the Environmental Crisis? Sustainability, Liberal Neutrality and Overlapping Consensus. In A. Dobson, \& P. Lucardie (Eds.), The Politics of Nature: Exploration in Green Political Theory (p. 86). Abingdon-on-Thames: Routledge.

Adams, W. M. (2001). Green Development: Environment and Sustainability in the Third World (2nd ed., pp. 1-2). Abingdon-on-Thames: Routledge.

Adeoluwa, R. O. (2018). Appraisal of the Operationalisation of National Environmental Regulations in Nigeria under the National Environmental Standards and Regulations Enforcement Agency. Nnamdi Azikiwe University Journal of International Law and Jurisprudence, 9, 199-215.

Akinsulore, A. (2017-2018). Evolving a Legal Framework for Sustainable Development and Utilisation of Nigeria's Bitumen Resources. Nigerian Current Law Review, 194, 224.

Ako, R. T. (2006). Ensuring Public Participation in Environmental Impact Assessment of Development Projects in the Niger Delta of Nigeria: A Veritable Tool for Sustainable Development. Environtropica, 3, 1.

Alao, D. O. (2015). Interrogating the Involvement of Native Gods in Contemporary African Conflict Management. Global Journal of Politics and Law Research, 3, 57-71.

Amokaye, O. (2014). Environmental Law and Practice in Nigeria (7th ed., p. 131). Lagos: 
MIJ Professional Publishers Ltd.

Anand, S., \& Sen, A. (1997). Concepts of Human Development and Poverty: A Multidimensional Perspective. Human Development Paper 1.

Anand, S., \& Sen, A. (2007). Concept of Human Development and Poverty: A Multidimensional Perspective.

http://clasarchive.berkeley.edu/Academics/courses/center/fall2007/sehnbruch/UNDP\% 20Anand\%20and\%20Sen\%20Concepts\%20of\%20HD\%201997.pdf

Anderson, M. R. (1998). Human Rights Approach to Environmental Protection: An Overview. In A. E. Boyle, \& M. R. Anderson (Eds.), Human Rights Approaches to Environmental Protection (pp. 1-9). Oxford: Clarendon Press.

Baker, S. (2006). Sustainable Development (p. 20). Abingdon-on-Thames: Routledge, Taylor and Francis Group.

Baker, S., Kousis, M., Richardson, D., \& Young, S. (1997). The Politics of Sustainable Development: Theory, Policy and Practice within the European Union (p. 3). Abingdon-on-Thames: Routledge.

Banerjee, D. K. (2012). Oil Sands, Heavy Oil \& Bitumen: From Recovery to Refinery. Tulsa, OK: Pennwell Corporation.

Berend, I. T. (2006). An Economic History of Twentieth-Century Europe: Economic Regimes from Laissez-Faire to Globalization. Cambridge: Cambridge University Press. https://doi.org/10.1017/CBO9780511800627

Brundtland, G. (1987). Our Common Future. Report of the World Commission on Environment and Development, United Nations Assembly Document A/42/427.

Brundtland, G. H. (2018). Social Solidarity for Sustainable Development. Project Syndicate.

https://www.project-syndicate.org/commentary/sdgs-climate-change-solidarity-by-gro -harlem-brundtland-2018-09?barrier=accesspaylog

Brundtland, G. H. (2020). Leading in a Complex World, in Jeffrey Sachs (Moderator) Conversations with Global Leaders: Leading on Sustainable Development.

https://courses.edx.org/courses/course-v1:SDGAcademyX+LSD001+1T2020/coursewar e/098da865403e43b3bd9084089f49d4e1/0755c7af48324cf39083bbf33d9535f5/?child=las $\mathrm{t}$

CEIA (1991). Convention on Environmental Impact Assessment in a Transboundary Context. http://www.unece.org/

Chindo, M. (2015). Environmental Risks Associated with Developing Oil Sands in Southwestern Nigeria. Singapore Journal of Tropical Geography, 36, 3-22. https://doi.org/10.1111/sjtg.12091

Chiwendu, O. B., \& Osimiri, U. J. (2020). The Jurisprudence of Compliance and Enforceability of Environmental Protection Laws in Nigeria. Journal of Law, Policy and Globalization, 93, 147-153.

Dare, K. O. (2009). Situating Local Knowledge within Development Agenda: Some Reflections. Consilience, No. 2, Article No. 5.

Dawe, N. K., \& Ryan, K. L. (2003). The Faulty Three-Legged-Stool Model of Sustainable Development. Conservation Biology, 17, 1458-1460. https://doi.org/10.1046/j.1523-1739.2003.02471.x

Egunjobi, L. (1993). Issues in Environmental Management for Sustainable Development. Environmentalist, 13, 33-40. https://doi.org/10.1007/BF01905501

Etemire, U. (2014). Public Access to Environmental Information: A Comparative Analy- 
sis of Nigerian Legislation with International Best Practice. Transnational Environmental Law, 3, 149-172. https://doi.org/10.1017/S2047102513000575

Etemire, U. (2018). A Fresh Perspective on the Human Right to Political Participation and Environmental Decision-Making in Nigeria. African Journal of International and Comparative Law, 26, 565-584. https://doi.org/10.3366/ajicl.2018.0249

Eyo, E. (1990). Two Thousand Years of Nigeria Art (p. 32). Lagos: Ethnographica.

Fagbemi, S. A., \& Akpanke, A. R. (2019). Environmental Litigation in Nigeria: The Role of the Judiciary. Nnamdi Azikiwe University Journal of International Law and Jurisprudence, 10, 26-34.

Fayemi, K. (2015). State of the Solid Mineral Sector and the Way Forward. http://thenewsnigeria.com.ng/wp-content/uploads/2015/12/SOLID-MINERALS-PRES S-BRIEFING-FINAL1.pdf

Frynas, J. G. (1999). Legal Change in Africa: Evidence from Oil-Related Litigation in Nigeria. Journal of African Law, 43, 121-150. https://doi.org/10.1017/S0021855300011311

Grant, J., Angen, E., \& Dyer, S. (2013). Forecasting the Impacts of Oilsands Expansion Measuring the Land Disturbance, Air Quality, Water Use, Greenhouse Gas Emissions, and Tailings Production Associated with Each Barrel of Bitumen Production (p. 1). Calgary: Pembina Institute.

Haq, M. (2006). Human Development Report-UNDP.

Holy Bible (2003). Authorised King James Version Thomas Nelson Bibles, Genesis Chapter 1 verse 28 .

Ikale Voice News Report (2020). Irele Local Government Caretaker Chairman Inaugurates Technical Committee on EIA. http://www.ikalevoice.com

Ingelson, A., \& Nwapi, C. (2014). Environmental Impact Assessment Process for Oil, Gas and Mining Projects in Nigeria: A Critical Appraisal. Law, Environment and Development Journal, 10, 35.

Jordaan, S. M. (2012). Land and Water Impacts of Oil Sands Production in Alberta. Environmental Science \& Technology, 46, 3611-3617. https://doi.org/10.1021/es203682m

Kanbur, R. (2018). Gunnar Myrdal and Asian Drama in Context. Centre for Economic Policy Research Discussion Paper DP2590. https://doi.org/10.35188/UNU-WIDER/2018/544-2

Ladan, M. T. (2012). Review of NESREA Act 2007 and Regulations 2009-2011: A New Dawn in Environmental Compliance and Enforcement in Nigeria. Law, Environment and Development Journal, 8, 116.

Lord, K. (2019). Adapting Global Development in a Two-Tiered World. Future Development.

https://www.brookings.edu/blog/future-development/2019/04/04/adapting-global-deve lopment-in-a-two-tiered-world/

Milos, C. (2015). Bitumen in Nigeria, Weighing the True Costs of Extraction. Heinrich Böll Foundation Nigeria. https://ng.boell.org/sites/default/files/bitumen_in_nigeria.pdf

Mmadu, R. A. (2013). Judicial Attitude to Environmental Litigation and Access to Environmental Justice in Nigeria: Lessons from Kiobel. Afe Babalola University: Journal of Sustainable Development Law and Policy, 2, 149-170.

Myrdal, G. (1968). Asian Drama: An Inquiry into the Poverty of Nations (Vol. I, II \& III, pp. 57-67). New York: Pantheon.

Natural Resource Governance Institute (NRGI) Reader (2015). Extractives-Linked Infrastructure: Exploring Options for Shared Use of Infrastructure Projects. 
https://resourcegovernance.org/sites/default/files/nrgi_Extractives-Linked-Infrastructu re.pdf

Nayar, K. R. (1994). Politics of Sustainable Development. Economic and Political Weekly, 29, 1328.

NESREA Laws and Regulations (2020). https://www.nesrea.gov.ng/publications-downloads/laws/regulations/

Njiro, E. (2002). Introduction: Sustainable: Development and Oxymoron? In Agenda: Empowering Women for Gender Equity (No. 52, pp. 3-7). Abingdon-on-Thames: Taylor \& Francis, Ltd.

Nwapi, C. (2008). Environmental Democracy and Compliance with Multilateral Environmental Agreements: The Significance of the Aarhus Compliance Method. UBC International Law Journal, 1, 18-36.

Nwapi, C. (2015). Environmental Sentencing Policy in Alberta: A Critical Review. CIRL Occasional Paper \#46, 1.

Nwapi, C. (2016). Can the Concept of Social Licence to Operate Find Its Way into the Formal Legal System. Flinders Law Journal, 18, 349-375.

Nwauzi, L. O., \& Fab-Eme, C. D. (2019). Re-Examining the Protection of the Environment under the 1999 Constitution and International Instruments. Journal of Law, Policy and Globalization, 89, 207-213.

Ogbuabor, C. A. (2014). Tribunals of Inquiry as a Residual Matter under the Nigerian Constitution: Resolving the Nigerian Conundrum. African Journal of International and Comparative Law, 22, 273-307. https://doi.org/10.3366/ajicl.2014.0093

Ogunba, A. (2016). An Appraisal of the Evolution of Environmental Legislation in Nigeria. Vermont Law Review, 40, 673-694.

Ojo, G. U., \& Oluwafemi, A. (Eds.) (2004). Before the Earth Bleeds Again (pp. 82-86). Lagos: Environmental Rights Action/Friends of the Earth.

Ojobgo, S. E. (2018). Public Participation and Environmental Degradation in Developing Markets: The Challenges in Focusing on Environmental Impact Assessment (EIA) in Nigeria. Legal Issues Journal, 6, 37.

Okon, E. E. (2016). The Legal Status of Sustainable Development in the Nigerian Environmental Law. Journal of Sustainable Development Law and Policy, 7, 104-134. https://doi.org/10.4314/jsdlp.v7i2.6

Okonkwo, T. (2018). Remedies for Environmental Damage under the National Environmental Standards and Regulations Enforcement Agency (NESREA) (Establishment) Act 2007 and the Harmful Waste (Special Criminal Provisions, etc) Act 1988. Nnamdi Azikiwe University Journal of International Law and Jurisprudence, 9, 127-137.

Okorodudu-Fubara, M. (1998). Law of Environmental Protection: Materials and Text. Ibadan: Caltop Publication Ltd.

Olaniyan, A. (2015). The Law and Multi-Agency Response to Oil Spill Incidents in Nigeria (p. 1). Amsterdam: InterSpill.

Olawuyi, D. S. (2015). The Principles of Nigerian Environmental Law (p. 43). Ado-Ekiti: Afe Babalola University Press.

Olawuyi, D. S., \& Olusegun, O. O. (2018). Achieving the United Nations Sustainable Development Goals on Biological Diversity in Nigeria: Current Issues and Future Directions. Global Journal of Comparative Law, 7, 37-60.

https://doi.org/10.1163/2211906X-00701003

Omorogbe, Y. (2002). The Legal Framework for Public Participation in Decision-Making 
on Mining and Energy Development in Nigeria: Giving Voices to the Voiceless. In D. M. Zillman, A. Lucas, \& G. (Rock) Pring (Eds.), Human Rights in National Resource Development (pp. 549-568). Oxford: Oxford University Press. https://doi.org/10.1093/acprof:oso/9780199253784.003.0015

Orji, U. J. (2012). An Appraisal of the Legal Framework for the Control of Environmental Pollution in Nigeria. Commonwealth Law Bulletin, 38, 321-346. https://doi.org/10.1080/03050718.2012.674735

Owoyemi, O., \& Bamigboye, O. (2013). Contemporary Environmental Impact Assessment Issues in Nigeria. RMZ-M\&G 219, 220.

Prendergast, R. (2005). The Concept of Freedom and its Relation to Economic Development-A Critical Appreciation of the Work of Amartya Sen. Cambridge Journal of Economics, 29, 1145-1170. https://doi.org/10.1093/cje/bei081

Pring, G., \& Noe, S. Y. (2002). The Emerging International Law of Public Participation Affecting Global Mining, Energy, and Resources Development. In D. N. Zillman, A. R. Lucas, \& G. Pring (Eds.), Human Rights in National Resource Development: Public Participation in the Sustainable Development of Mining and Energy Resource (p. 22). Oxford: Oxford University Press. https://doi.org/10.1093/acprof:oso/9780199253784.003.0002

Raji, A. O. Y., \& Abejide, T. S. (2013). The Guild System and Its Role in the Economy of Pre-Colonial Yorubaland. Arabian Journal of Business and Management Review, 3, 14-22. https://doi.org/10.12816/0016425

Reyes, G. E. (2001). Four Main Theories of Development: Modernization, Dependency, Word-System and Globalization. Sincronía, 4, 2.

Sachs, L., \& Maennling, N. (2015). Resource Resilience: How to Break the Commodities Cycle. World Politics Review, 1, 6.

Sonesson, C., Davidson, G., \& Sachs, L. (2016). Mapping Mining to the Sustainable Development Goals: A Preliminary Atlas. World Economic Forum, 1, 7.

Speight, J. G. (2016). Introduction to Enhanced Recovery Methods for Heavy Oil and Tar Sands (2nd ed., pp. 386-397). Houston, TX: Gulf Professional Publishing.

Stevens, L. (2011). Illusion of Sustainable Development: How Nigeria's Environmental Laws are Failing the Niger Delta. Vermont Law Review, 36, 387-407.

Tetlow, M. F., \& Hanusch, M. (2012). Strategic Environmental Assessment: The State of the Art. Impact Assessment and Project Appraisal, 30, 15-24.

https://doi.org/10.1080/14615517.2012.666400

Udombana, N. J. (2000). The Third World and the Right to Development: Agenda for the Next Millennium. Human Rights Quarterly, 22, 753-787. https://doi.org/10.1353/hrq.2000.0038

UN Environment Programme Press Release (UNEP) (2018). Bamako Convention: Preventing Africa from Becoming a Dumping Ground for Toxic Wastes. https://www.unep.org/news-and-stories/press-release/bamako-convention-preventingafrica-becoming-dumping-ground-toxic

UNEP (1987). Goals and Principles of Environmental Impact Assessment in UNEP: An Approach to Environmental Impact Assessment for Projects. http://www.unep.org/

United Nations Department of Economic and Social Affairs (UNDESA) (2015). Sustainable Development: The 17 Goals. https://www.un.org/en/desa

United Nations Development Programme (UNDP) (2019). Sustainable Development Goals.

https://www.undp.org/content/undp/en/home/sustainable-development-goals.html 
Watmore, S. (2013). Tar Sands Oil and Pipeline Safety: Examining Regulatory Shortcomings. Wayne Law Review, 59, 175-180.

Weinhold, B. (2011). Alberta's Oil Sands: Hard Evidence, Missing Data, New Promises. Environmental Health Perspectives, 119, A126-A131. https://doi.org/10.1289/ehp.119-a126

Williams, C., \& Millington, A. (2004). The Diverse and Contested Meaning of Sustainable Development. The Geographical Journal, 170, 99-104. https://doi.org/10.1111/j.0016-7398.2004.00111.x

World Conference on Environment and Development (WCED) (1987). 8-9. 